観察し，真珠腫とその他の症例で差が認められるかど うかを検討した。

対象は高分解能 CT を施行した73耳であり，内訳は 正常耳15耳, 中心穿孔型慢性中耳炎31耳, 真珠腫 $\mathrm{L}$ (耳 管上宿凹に進展していないもの) 22 耳，真珠腫 $\mathrm{E}$ (耳管 上樎凹進展例) 5 耳である。撮影には GE-9800 用い,

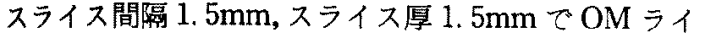
ンに平行な軸位断で施行した。 耳管上陥凹の観察には 外側半規管全体の描出面から,このスライスの $4.5 \mathrm{~mm}$ 下方の面まで計 4 つのスライスを用いた．耳管上陥凹 の前後径および左右径を外側半規管描出面より下方 $3 \mathrm{~mm}, 4.5 \mathrm{~mm}$ のスライスにて計測し, 各タイプ毎に差 があるかどうかを調べた。また $\operatorname{cog}$ の描出されるスラ イス数についても調べた。

結果としては，耳管上陥山の前後径，左右径の計測 值は真珠腫 Eにて若干長い傾向がみられたが統計的 には有意差は無く，その他の症例では差は見られなか

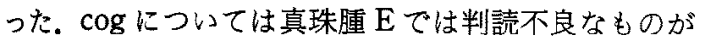
多く, 中心穿孔型慢性中耳炎, 真珠腫 Lでも若干不良
であった。これは病変による骨破懐の他に, partial volume effect や空間分解能の影響と思われた。

耳管上陥凹という小さくかつ個体差のある空間を CTのみにて評価することには限界があるが，今回の 険討の結果からは真珠腫とその他の症例ではこの陥凹 の骨性形態には差はみられなかった。このことから， 真珠腫の発症に耳管上楩凹の大きさ・形態はあまり関 与していないことが示唆されたものと考えている。

質問 星野知之(浜松医大).1) CTで耳管上楩凹の夕 イプを鑑別することは可能か.2）真珠腫の発生を考之 る上では骨腔の形よりも粘膜七ダの状態がより関係す ると思うが如何か. 応答 1) CT では耳管上楩以 のタイプ別分類は不可能である.2）骨性形態では真珠 腫とその他の症例に差がないということであり粘膜ひ だの関与については評価できない。

質問 坂井 真(東海大)。耳管上陥山性下時すでに発育され，完 成されているものか. 応答 生下時に耳管上陷山 があるかどうかの報告は私の知る範囲ではまだない。

\title{
47. 真珠腫性中耳炎の電顕的観察
}

\author{
増田成夫・川端五十鈴・中村雅一・近藤玲子（埼玉医大総合医療センター）
}

目的 真珠腫性中耳炎では周辺の骨破壊が高頻度に かつ広沉に生じ，高度の病変となり，種々の合併症を 生じることが多い，そのため古来より骨破壊機序につ いて多くの研究が行われている，骨破壊に対して压迫 説，炎症に上る循環障害説，䣲素活性に上る骨吸収説 などの仮説が提唱されているが，いまだに骨破壊の病 態は充分に解明されていない.今回私共は骨破壊の機 序を知る目的で走查, 透過電顕的に真珠腫に接する骨 破壞の境界面を観察したところ，2〜3の興味ある所 見が得られたので，ここに報告した。

研究材料と研究方法 当科で手術を施行した真珠腫 性中耳炎症例を用いた。真珠腫の matrix をつけたま ま骨の小片を採取し, 通常の走查電顕, 透過電䫓の試 料作製法に従って標本を作成した。

結果 走㚗電影で観察すると骨破壊面に接する真珠 霾の上皮は扁平な多角形の細胞よりなり，重層構造を なしている。細胞の表面に多少の凹凸がみられ，その 一部は細胞間橋を思わせるものもある。骨破壊面に直
接に接する細胞の表面は多数の凹凸があり，一部は隆 起をなしている．骨破壊面では毛細血管や赤血球の集 合があり出血巣を思わせる部位がみられた。大部分の 表面では縦横に走行する線維状の構造がみられる。多 様の太さを示す線維状構造の他に，膠原線維に相当す る線維のみが走行する部位もあり，そこでは線維芽細 胞が観察される。しかし少なくとも破骨細胞・骨細胞 は前述の上皮細胞直下にはみられなかった。透過電䫓 の所見についても報告した。

結語 真珠腫性中耳炎における骨破壊機序を検討す るため, 真珠腫に接する骨破壞の境界面について走 査・透過電顕で観察したので，その所見を述べた。 質問 鈴木聡明(福島医大)。真珠腫マトリックスに断 裂したような所見はなかったか，もしあれば電顕的所 見について。応答 断裂面は今回の観察では認め られなかったが，骨破壊像を呈している部分は，断裂 面以外でも見ら机た。

\section{8. 中耳真珠腫および retraction pocket の炎症病態について}

\section{一七ト側頭骨病理組織学的研究—}

\author{
鈴木聡明・相川 通・大谷 䈣（福島医大）
}

緒言 上鼓室型真珠腫の成立機転についてはいまま で数多くの報告か゚なされ, 鼓膜弛緩部の陷凹（以下 dimple と略す), retraction pocket が真珠腫形成の一 過程を構成すると考えられている。 今回, dimple, 